\title{
VALUES AND VALUATIONS IN JUDICIAL DISCOURSE. A CORPUS-ASSISTED STUDY OF (DIS)RESPECT IN US SUPREME COURT DECISIONS ON SAME-SEX MARRIAGE
}

\begin{abstract}
This paper investigates the role of (DIS)RESPECT a value premise in two landmark civil rights cases given by the United States Supreme Court. It adopts a corpus-assisted approach whereby a keyword analysis and the analysis of key semantic domains are used to identify potential values relied upon by judges in their justifications. The two categories of NO RESPECT and RESPECTED have been selected and examined as one domain of (DIS)RESPECT. (DIS)RESPECT turns out to be the only value marked by strong evaluative polarity and it is found in the majority, as well as in dissenting opinions. The analysis shows how the notion of (DIS)RESPECT has been integrated into the arguments of judges and it highlights the central importance of values and the related evaluative language for legal argumentation.
\end{abstract}

Keywords: axiology, evaluation, judicial discourse, corpus-assisted discourse analysis, legal argumentation, same-sex marriage.

On June 26, 2015, the United States Supreme Court ruled gay couples nationwide had a right to marry. The decision passed narrowly, with a 5-4 vote. As a result, the United States became the 18th nation to grant the right to same-sex couples. Same-sex marriage and its legal status has proved to be one of the most divisive issues not only in American society but also among the US Supreme Court judges. The legal battles have been fought through language, which is inevitably highly evaluative and it reflects different and conflicting value systems. Any stance articulated in different evaluative acts represents not only the judge's own individual position, but it is also a position that reflects the epistemological beliefs and values of a community (cf. Thompson, G. \& Alba Juez 2014). Further, evaluation and legal argumentation are inextricably linked. The purpose of any legal justification is to define the reasons and arguments for reaching a particular decision. In order to do so, judicial argumentation may embrace specific 
values as a starting point. Perelman and and Olbrechts-Tyteca (1969) argue that values enter, at some stage or other, into every argument" and this is particularly characteristic of law, politics and philosophy where "values intervene as a basis for argument at all stages of the development"1. As Zimmermann (2015) emphasizes, legal norms are embedded within values. The justification for a legal norm may be derived from the authority of an institution which creates a legal norm. The power and authority of this institution provide sufficient grounds for the norm to be enforceable. However, it is equally important that the norm has a solid axiomatic base which is socially approved and complied with, even if the authority of the institution has been weakened.

This paper examines the axiomatic component of the argumentation contained in two recent landmark US Supreme Court opinions on samesex marriage: United States v. Windsor, and Obergefell et al. v. Hodges et al. In the former case, two New York residents Edith Windsor and Thea Spyer obtained a same-sex marriage in Canada and returned home to New York $^{2}$. New York did not yet issue marriage licenses to same-sex couples, but the state began recognizing such "marriages" from other jurisdictions in 2008. When Spyer died in 2009, she left her estate to Windsor, who then sought a spousal exemption from the federal estate tax. Because of the federal Defence of Marriage Act (from now on referred to as DOMA), the exemption was denied. Windsor then challenged Section 3 of DOMA as unconstitutional. DOMA had two substantive provisions: Section 2 provided that states would not be required to recognize same-sex "marriages" from other states; Section 3 provided that for all purposes under federal law, marriage would be defined only as the union of one man and one woman.

The Supreme Court judges had to address the essential question of whether the DOMA, which defines the term "marriage" under federal law as a "legal union between one man and one woman" deprives same-sex couples, who are legally married under state laws of their Fifth Amendment rights, to equal protection under federal law. The Court responded in the affirmative. In the latter case, several same-sex couples sued their state agencies for failing to recognize legal same-sex marriages that occurred in jurisdictions that provided for such marriages. In doing so, they set out to challenge the constitutionality of those states' bans on same-sex marriage citing Fourteenth Amendment rights to equal protection and due process. The Supreme Court focused on two issues: (1) whether the Fourteenth Amendment required a state to license a marriage between two people of the same sex and (2) whether the Fourteenth Amendment required a state to recognize a marriage between two people of the same sex that was legally 
licensed and performed in another state. As in the previous case, the judges answered these questions in the affirmative. The outcome of the case has been hailed as a landmark victory for the civil rights movement. In both cases, the decisions were reached through a 5-4 majority showing the extent to which the court was divided over this issue.

What remains the crucial question from the axiomatic perspective is the manner and the extent to which values and evaluative language were relied upon or referred to in the judicial justifications of these two decisions. In this paper, I argue that values are used as premises for a substantial part of the argumentation in both majority and minority opinions. This means that values constitute the starting point for the argumentation and their presence may account for the way in which the argument is developed. Accordingly, this study aims to address the following questions: what values, if any, the judges invoke in their opinions? How do the opinions differ in the way they use values in their argumentation depending on whether they are majority opinion or dissenting opinion. Given the polarity of opinion revealed in the split decisions, one would expect to notice considerable variation in how evaluation is used by the Supreme Court judges in these two cases.

\section{Values and Evaluation in Legal Discourse}

This paper adopts a linguistic perspective towards the study of values by resorting to the evaluative function of language in order to express them (Alba-Juez and Geoff Thompson 2014). The study of values and evaluative meanings from the linguistic perspective in judicial discourse is a relatively under-researched area. Most studies focus on particular words or phrases that have been previously identified as either intrinsically or potentially evaluative. For example, in his corpus-based study, Mazzi (2010) investigates evaluative lexis in the judicial discourse of US Supreme Court written opinions. By focusing on the single discourse element of 'this/these/that/those + the labelling noun', he provides some corpus evidence to demonstrate that abstract nouns such as, for example, attitude, difficulty, process, reason, etc. have both encapsulating and evaluative functions when found in this pattern in the judicial opinions. In a similar vein, Goźdź-Roszkowski \& Pontrandolfo (2013) analyzes nouns followed by that-clause in US and Italy's Supreme Courts' opinions. ${ }^{3}$ These studies typically draw upon the concept of evaluation understood as a set of linguistic expressions which 
are used by speakers or writers to communicate their attitudes, stances or emotive responses to the propostions they are talking about (cf. Thompson and Hunston 2000: 5).

In this study, I adopt a slightly different approach which starts from identifying a lexeme denoting a value. The rather complex notion of 'value' is here reduced to 'professional value', understood simply as "qualities which define what is prized or stigmatized by different professional communities" (Breeze 2011: 94). I use the notion of professional value to bring light to how judges express their approval or disapproval in their opinions. I examine both the value and its related evaluative language in keeping with the understanding of evaluation as language function used to express a user orientation (it is the user who evaluates) but also the expression of "values ascribed to the entities and propositions which are evaluated" (Thompson and Hunston 2000: 5).

\section{Data and the Institutional Context}

The opinions explored in this study were handed down by the United States Supreme Court, which is the highest appeal court as well as a constitutional court, i.e. its task is to ensure the constitutionality of laws created in the United States. American law is judge-made law as it is heavily based on judicial precedent. The polyphony of judicial voices is reflected in the various types of opinion available to the judges: majority opinion, concurring opinion and dissenting opinion. The US Supreme Court is the highest court in the United States. It consists of the Chief Justice and eight Associate Justices who are nominated by the president and confirmed by the Senate. Its primary task is to exercise appellate jurisdiction and to serve as the final arbiter in the construction of the Constitution of the United States by providing a uniform interpretation of the law. Appellants must file a petition for writ of certiorari, i.e. they ask the Court to hear their appeal. The certiorari can be either granted or denied. If it is granted, the Court will deliver one of the following opinions: per curiam opinion (unanimous), majority (opinion shared by the majority), plurality (final outcome agreed to by majority but for differing reasons). Individual judges (referred to as justices) can also write their separate opinions, which are either concurring (agreeing with the majority decision for different reasons) or dissenting opinion (disagreeing with the majority). It is not possible to appeal from a S.C. decision. The decisions are binding in all jurisdictions in the United States but the Supreme Court may overrule its own decisions. 
Opinions delivered by the Supreme Court of the United States (SC) generally consist of four major parts (Brostoff and Sinsheimer 2003):

(1) headnote - which includes the names of the parties, identification of parties (their role in the proceedings, i.e. petitioner, respondent), an identification of the court in which the recorded case was heard, and the date of the opinion;

(2) Procedural History - this section contains a brief description of how the lower-instance courts dealt with the case. It usually includes the basis for review, i.e. the reasons why the Supreme Court heard the case;

(3) Holding - this section provides the decision (ruling) reached by the Supreme Court in a particular case ended with a disposition of the case (e.g. affirmed, vacated and remanded);

(4) Opinion - unlike the previous sections which are usually prepared by a court clerk, this final part is authored by individual judges and it includes judicial argumentation provided in order to justify the decision reached by the court. It explains the law as applied to the case and provides the reason on the basis of which the decision is made.

This analysis carried out for the purpose of this study used two major data sets: the majority opinions and the dissenting opinions written in the two cases of United States v. Windsor, and Obergefell et al. v. Hodges et al. In both these cases, Justice Anthony M. Kennedy delivered the opinion of the court (majority opinion). The dissenting opinions in United States $v$. Windsor were written by Chief Justice Roberts, Justice Scalia, and Justice Alito. In the Obergefell et al. v. Hodges et al., there were as many as four dissenting opinions, which means that each judge who voted against the decision chose to write their own opinion. These included Chief Justice C.J. Roberts, the late Justice Scalia, Justice Thomas and Justice Alito.

\section{Methodology}

This study incorporates quantitative methods to reveal words which can potentially denote values or evaluative language but it also relies on close reading of co-texts surrounding these words to determine their semantic content and the function they perform in the analyzed texts. The methodological approach adopted here is thus close to what is now known as corpus-assisted discourse studies or CADS. Partington (2004) is credited with coining this term and defining it as: "that set of studies into the form and/or function of language as communicative discourse which incorporate the use of computerised corpora in their analyses" (cited in Partington et al. 
2013: 10). According to this approach, the use of computerised corpora and computational tools provides output which is treated as a starting point for a detailed and thorough qualitative analysis which examines not only the immediate co-texts of a given lexical item but also the wider institutional, social or legal contexts in which the analyzed text or texts are embedded.

The initial computational stage of the analysis was carried out by means of two programmes: WordSmith Tools 5.0 and the Wmatrix $3^{4}$. While the former is a relatively well-known suite of text-processing tools (Scott 2008), Wmatrix 3 needs a word of introduction. It is the web interface to the USAS and CLAWS corpus annotation tools developed at Lancaster University. This tool enables one to study the characteristics of whole texts by identifying key words and key semantic domains. This is possible by assigning part-of-speech and semantic field (domain) tags which leads to the extraction of key domains by applying the keyness calculation to tag frequency lists (Rayson, 2008).

The concept of a keyword is by no means new and it can refer to at least two senses. The original one is associated with a lexical item which is considered key because of its cultural, historical or social importance (see Williams 1995). However, in contemporary corpus linguistics, a keyword is understood as a statistically significant word form. Scott (2008) refers to keywords as "those words whose frequency is unusually high in comparison with some norm". By and large, any keyword analysis involves comparing two lists. One wordlist is based on the words from a collection of texts which is the object of analysis, i.e. majority and dissenting opinions in this study. The other wordlist is a larger reference list. Selecting a reference corpus is crucial if we want to identify keywords that most adequately characterize a particular collection of texts. The keyword results are bound to be affected by the reference corpus. For example, if a wordlist extracted from the corpus of judicial opinions was compared against a general language corpus such as the British National Corpus or Corpus of Contemporary American English, the resulting keyword would inevitably include words related to general legal language and procedure such as court, federal, state, law, proper names related to institutions and names of the legal interactants. ${ }^{5}$ To illustrate this issue, the wordlists for majority and dissenting opinions were first compared against the BNC sample of written language using Wmatrix 3. Then, keywords were generated relying on the corpus of US Supreme Court decisions as a reference corpus. In this way, one expected to obtain results which are unique to the two opinions but at the same time relative to other Supreme Court opinions. 
Based on these outputs, various categories of keywords were proposed in an attempt to identify prevalent themes in the two types of opinions. The keyword analysis was augmented by the analysis of key semantic domains. It is argued that, combined, these sources of data provide a solid basis for selecting dominant values permeating the judicial justification in these two cases. The next stage involved scrutinizing the concordances of selected words denoting concepts perceived as values to determine their role in legal justification and argumentation.

\section{Results and Discussion}

\section{Keywords and key semantic domains}

The first stage of the keyword analysis involved identifying keywords in majority opinions and dissenting opinions to find out whether these two types of judicial opinion are characterized by similar or different keywords. The results of the analysis are shown in Table 1 and Table 2, which provide 25 most key words in the two respective categories.

Table 1 shows results for the keyword analysis in the majority opinions sorted according to significance using Wmatrix. Items in bold are found in both types of opinion. $\mathrm{O} 1$ is observed frequency in majority opinions. $\mathrm{O} 2$ is observed frequency in the reference corpus (BNC Written). $\% 1$ and $\% 2$ values show relative frequencies in the texts. The table is sorted on loglikelihood (LL) value.

Table 1

\begin{tabular}{|l|r|r|r|r|r|}
\hline \multicolumn{1}{|c|}{ Item } & o1 & $\mathbf{~ \% 1}$ & $\mathbf{~ o 2}$ & $\mathbf{~ \% 2}$ & LL \\
\hline v. & 194 & 1.15 & 11 & 0.00 & 1493.69 \\
marriage & 168 & 1.00 & 80 & 0.01 & 1058.31 \\
same-sex & 112 & 0.67 & 0 & 0.00 & 911.62 \\
court & 31 & 0.78 & 141 & 0.01 & 694.43 \\
couples & 84 & 0.50 & 2 & 0.00 & 664.79 \\
U._S. & 51 & 0.30 & 0 & 0.00 & 415.11 \\
F.Supp. & 51 & 0.30 & 0 & 0.00 & 415.11 \\
DOMA & 43 & 0.26 & 0 & 0.00 & 350.00 \\
states & 46 & 0.27 & 6 & 0.00 & 337.43 \\
2014 & 41 & 0.24 & 0 & 0.00 & 333.72 \\
federal & 55 & 0.33 & 34 & 0.00 & 330.47 \\
marry & 51 & 0.30 & 39 & 0.00 & 293.30 \\
2d & 34 & 0.20 & 0 & 0.00 & 276.74 \\
\hline
\end{tabular}




\begin{tabular}{|l|c|c|r|r|l|}
\hline \multicolumn{1}{|c|}{ Item } & o1 & \%1 & o2 & \%2 & LL \\
\hline UNITED_STATES & 50 & 0.30 & 51 & 0.01 & \\
3d & 32 & 0.19 & 1 & 0.00 & 251.54 \\
2013 & 32 & 0.19 & 1 & 0.00 & 251.54 \\
marriages & 34 & 0.20 & 6 & 0.00 & 243.13 \\
Windsor & 41 & 0.24 & 28 & 0.00 & 241.49 \\
state & 80 & 0.48 & 382 & 0.04 & 238.49 \\
courts & 37 & 0.22 & 19 & 0.00 & 230.07 \\
liberty & 29 & 0.17 & 3 & 0.00 & 216.24 \\
rights & 45 & 0.27 & 72 & 0.01 & 212.85 \\
law & 57 & 0.34 & 176 & 0.02 & 210.75 \\
supra & 24 & 0.14 & 0 & 0.00 & 195.35 \\
right & 75 & 0.45 & 479 & 0.05 & 187.66 \\
\hline
\end{tabular}

The comparison of the two tables shows that there is a considerable lexical overlap between the two types of opinion. There are as many as 12 identical word forms found in both lists. Not surprisingly, these include words such as marriage, couples or same-sex, which serve as a quick point of entry into the subject matter of the opinions. Indeed, the keywords analysis seems to be quite effective in identifying issues and themes prevalent in the judicial opinions. For example, the statistical salience of liberty which is a keyword in both datasets, can be accounted for in terms of the central importance of this concept in judicial argumentation. The majority opinions claim that same-sex marriage should be viewed as one of the fundamental rights and liberties protected by the Due Process Clause of the Fourteenth Amendment. In contrast, the dissenting opinions argue that the Fourteenth Amendment's requirement that "liberty" may not be deprived without "due process of law" does not apply, because no liberty has been denied $^{6}$. Interesingly, the quantitative analysis suggests that liberty is more frequently invoked in dissenting opinions.

Table 2 shows results for the keyword analysis in the dissenting opinions sorted according to significance using Wmatrix 3. Items in bold are found in both types of opinion.

Table 2

\begin{tabular}{|l|c|c|r|r|r|}
\hline \multicolumn{1}{|c|}{ Item } & o1 & \%1 & o2 & \%2 & \multicolumn{1}{c|}{ LL } \\
\hline Marriage & 310 & 0.97 & 43 & 0.01 & 1723.16 \\
court & 198 & 0.62 & 106 & 0.01 & 881.10 \\
v. & 144 & 0.45 & 11 & 0.00 & 841.80 \\
same-sex & 123 & 0.39 & 0 & 0.00 & 786.07 \\
\hline
\end{tabular}


Values and Valuations in Judicial Discourse...

\begin{tabular}{|l|r|r|r|r|c|}
\hline \multicolumn{1}{|c|}{ Item } & o1 & \%1 & o2 & \%2 & LL \\
\hline liberty & 123 & 0.39 & 12 & 0.00 & 706.09 \\
majority & 150 & 0.47 & 94 & 0.01 & 641.20 \\
ante & 99 & 0.31 & 1 & 0.00 & 621.58 \\
dissenting & 82 & 0.26 & 0 & 0.00 & 524.05 \\
U._S. & 75 & 0.24 & 0 & 0.00 & 479.31 \\
J. & 74 & 0.23 & 1 & 0.00 & 462.38 \\
that & 670 & 2.10 & 6066 & 0.81 & 425.44 \\
united_states & 91 & 0.29 & 51 & 0.01 & 400.40 \\
Id. & 62 & 0.19 & 0 & 0.00 & 396.23 \\
Petitioners & 62 & 0.19 & 1 & 0.00 & 386.04 \\
law & 116 & 0.36 & 164 & 0.02 & 375.16 \\
couples & 61 & 0.19 & 2 & 0.00 & 372.27 \\
constitution & 89 & 0.28 & 61 & 0.01 & 371.20 \\
opinion & 71 & 0.22 & 50 & 0.01 & 293.85 \\
right & 115 & 0.36 & 280 & 0.04 & 281.86 \\
states & 82 & 0.26 & 119 & 0.02 & 262.20 \\
amendment & 48 & 0.15 & 8 & 0.00 & 261.50 \\
judgment & 49 & 0.15 & 13 & 0.00 & 250.56 \\
constitutional & 59 & 0.19 & 43 & 0.01 & 241.77 \\
laws & 78 & 0.24 & 145 & 0.02 & 221.91 \\
federal & 52 & 0.16 & 34 & 0.00 & 219.74 \\
\hline
\end{tabular}

Further, dissenting opinions tend to refer to the concept of constitution or constutionality more often than the majority opinions. The occurrence of both state and federal in the opinions reveals that in legal terms, these cases are concerned with the relations between state and federal laws. In United States v. Windsor, it is the federal Defence of Marriage Act (DOMA) that was challenged and then found unconstitutional. The federal was at odds with the New York state law which recognized same-sex marriage.

The results provided in Tables 1 and 2 also demonstrate the limitation of using a general language corpus as a reference resource to generate keywords. This can be seen in the large proportion of items which highlight genrespecific lexis such as abbreviated forms commonly found in judicial opinions $(v ., i d$.$) , names of legal interactants (petitioners, majority, dissenting, U.S.),$ legal instruments (amendment, DOMA), etc. While this type of information could be extremely useful when describing judicial opinions as a separate genre, it is not particularly helpful if we want to determine the unique content of these two cases.

Another keyword analysis was thus carried out by comparing the wordlists from majority and dissenting opinions against the wordlist ex- 
tracted from the corpus of Supreme Court opinions. The results have corroborated that both majority and dissenting opinions rely on a very similar set of keywords. Table 3 shows the forty (40) most key words which occur in the two types of opinion. These keywords also overlap with several items listed in Table 1 and 2. Such items as marriage, same-sex, couples, liberty and constitution indicate not only the general subject matter of the case (the right of same-sex couples to marry), but they also begin to signal the prevalent axiomatic theme of the judicial argumentation contained in the opinions.

Table 3

Keywords shared in majority and dissenting opinions

\begin{tabular}{|l|r|r|r|r|l|l|r|c|r|r|r|}
\hline \multicolumn{1}{|c|}{ item } & O1 & $\mathbf{\% 1}$ & $\mathbf{O 2}$ & $\mathbf{\% 2}$ & keyness & item & O1 & \%1 & O2 & \%2 & keyness \\
\hline marriage & 486 & 0.95 & 10 & - & $3,095.24$ & opposite & 44 & 0.09 & 46 & - & 168.02 \\
sex & 300 & 0.59 & 52 & - & $1,682.72$ & man & 47 & 0.09 & 77 & - & 150.26 \\
couples & 142 & 0.28 & 1 & - & 921.89 & freedom & 47 & 0.09 & 93 & - & 137.37 \\
same & 289 & 0.57 & 986 & 0.08 & 611.10 & society & 45 & 0.09 & 83 & - & 136.15 \\
doma & 88 & 0.17 & 0 & - & 578.56 & protection & 74 & 0.15 & 339 & 0.03 & 123.96 \\
liberty & 155 & 0.30 & 0 & - & 564.62 & gays & 20 & 0.04 & 1 & - & 123.50 \\
marry & 85 & 0.17 & 2 & - & 539.94 & and & 1198 & 2.35 & 21972 & 1.68 & 120.62 \\
marriages & 58 & 0.11 & 0 & - & 381.29 & lesbians & 19 & 0.04 & 1 & - & 117.03 \\
institution & 57 & 0.11 & 23 & - & 280.48 & loving & 21 & 0.04 & 4 & - & 116.36 \\
majority & 136 & 0.27 & 481 & 0.04 & 279.97 & rights & 96 & 0.19 & 623 & 0.05 & 113.41 \\
right & 191 & 0.38 & 1227 & 0.09 & 228.48 & recognition & 35 & 0.07 & 63 & - & 107.13 \\
woman & 42 & 0.08 & 10 & - & 225.94 & couple & 19 & 0.04 & 4 & - & 103.94 \\
married & 38 & 0.07 & 5 & - & 219.27 & family & 37 & 0.07 & 89 & - & 97.44 \\
their & 251 & 0.49 & 2079 & 0.16 & 216.30 & marital & 18 & 0.04 & 5 & - & 94.61 \\
laws & 122 & 0.24 & 590 & 0.05 & 194.82 & definition & 57 & 0.11 & 267 & 0.02 & 93.62 \\
constitution & 127 & 0.25 & 670 & 0.05 & 186.90 & refund & 17 & 0.03 & 5 & - & 88.54 \\
dignity & 44 & 0.09 & 33 & - & 186.59 & spouse & 17 & 0.03 & 5 & - & 88.54 \\
people & 95 & 0.19 & 359 & 0.03 & 186.14 & intimacy & 13 & 0.03 & 0 & - & 85.45 \\
equal & 64 & 0.13 & 146 & 0.01 & 173.62 & women & 21 & 0.04 & 20 & - & 82.75 \\
fundamental & 65 & 0.13 & 158 & 0.01 & 170.20 & persons & 60 & 0.12 & 347 & 0.03 & 80.44 \\
\hline
\end{tabular}

The emerging axiomatic category based on the results in Table 3 includes the already mentioned liberty but also dignity, constitution, freedom and recognition. If we scrolled down the list beyond the first forty keywords, other value-laden words would appear, such as tradition, history, demean, equality or human. These results suggest that the judicial argumentation in these cases is to a large extent framed in terms of basic fairness and human dignity. Needless to say, apart from the legal questions, the social aspect becomes very prominent. 
In order to categorize items which most effectively characterize the judicial opinions, the Wmatrix tool was again used. This time, it served to identify semantic categories unique to the opinions. Table 4 provides the results. It lists key semantic concepts created by the program based on the semantic tags. These include law and order, relationship: intimacy and sex, kin, no respect, respected, understanding, power and comparing: different. Apart from the proposed categories, the program provides specific words which are salient in each category. Apart from the rather obvious category of legal terminology, the analysis highlights major themes emerging in the judicial opinions. The axiomatic aspect can be noticed not only in the two categories of NO RESPECT and RESPECTED, which are discussed in detail below, but also in the emphasis placed on familial relations manifested in the two categories of RELATIONSHIP: INTIMACY AND SEX and KIN. This clearly shows that the right of same-sex couples to marriage is not perceived in purely legal terms but against the wider social context involving the stability of marriage, parenthood and the traditional roles of husbands and wives.

\section{Table 4}

Key semantic concepts in majority and dissenting opinions

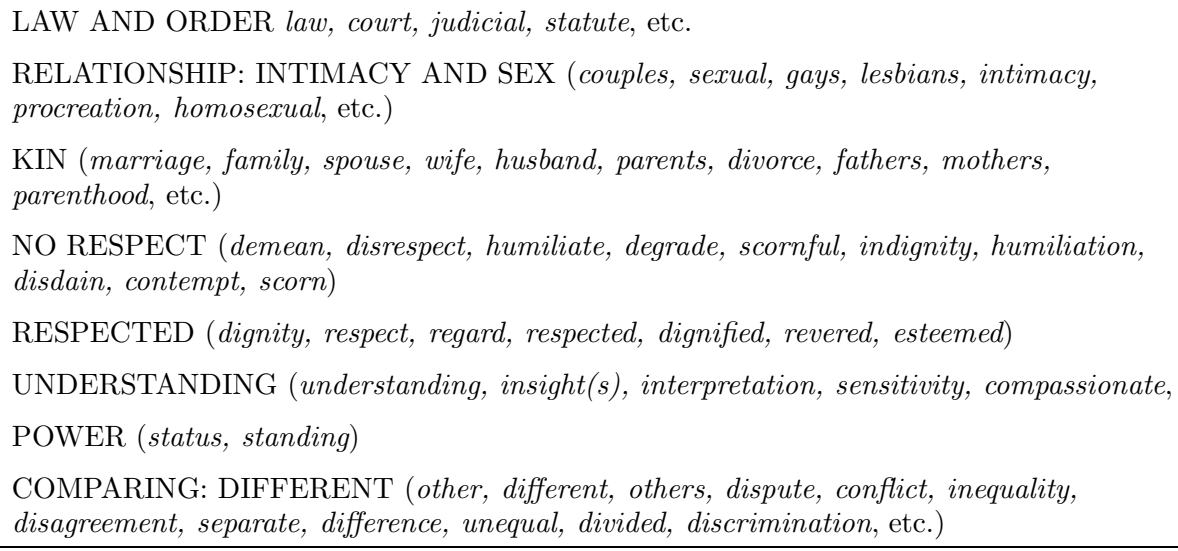

The two categories of NO RESPECT and RESPECTED signal the fundamental importance of respect as a value present in the judicial argumentation. It should be pointed out that these categories along with their corresponding lexical sets are found in both majority and dissenting opinions. It thus remains to be seen how judges use them to argue for fundamentally different dispositions of the case. In addition, RESPECT is the only concept framed in both positive and negative terms. A different category of COM- 
PARING: DIFFERENT contains lexical items which are inherently negative, such as ineqality, disagreement, divided, etc. The remaining results and discussion focus on determining how the concept of RESPECT in its positive and negative lexical manifestations is embraced in the two types of judicial opinion.

\section{The category of NO RESPECT in majority and dissenting opinions}

The analysis reveals that majority opinions tend to use these negativelycharged lexical items to assess the consequences that the challenged legislation (DOMA) has on same-sex couples. This is aptly illustrated in examples 1-3 below (emphasis in bold added):

(1) It demeans gays and lesbians for the State to lock them out of a central institution of the Nation's society.

(2) The imposition of this disability on gays and lesbians serves to disrespect and subordinate them.

(3) This places same-sex couples in an unstable position of being in a second-tier marriage. The differentiation demeans the couple, whose moral and sexual choices the Constitution protects, see Lawrence, 539 U. S. 558, and whose relationship the State has sought to dignify.

In Example 3, the negative consequence of the federal statute DOMA is flagged by the use of the words unstable, second-tier and demeans. It is contrasted with the role of the state (New York) appraised in positive terms by means of the word dignify. There seems to be a a certain symmetry in which the negative - positive evaluation is mapped onto the opposition between the federal and state law. Upon closer examination of the co-texts, there is an emerging textual pattern which the majority opinion uses to contrast the federal and state laws in United States v. Windsor. Examples 4 and 5 (emphasis added) provide further evidence for this discursive practice:

(4) DOMA seeks to injure the very class New York seeks to protect;

(5) DOMA singles out a class of persons deemed by a State entitled to recognition and protection to enhance their own liberty.

The outcome of this line of argumentation could be summarized in the following manner: The DOMA degrades same-sex couples because it excludes them from marriage and the enjoyment of intimate association. It also deprives them of a number of benefits that the state law links to marriage, which results in harm that goes beyond material concerns. It should be 
borne in mind that, in United States v. Windsor, if the marriage of Edith Windsor and Thea Clara Spyer had been recognized by federal law, the estate left by late Spyer would have qualified for a marital exemption, and no taxes would have been imposed.

Another major use of lexis related to NO RESPECT by the majority is to provide arguments against the claim that same-sex couples seek to undermine the institution of marriage. As examples 6 and 7 demonstrate, the majority are at pains to argue the opposite. Example 7 shows how the use of the negatively-loaded verb demean is mirrored by the repeated use of respect, which partly helps to further account for the strong occurrence of both negative and positive lexis related to the concept of RESPECT:

(6) Were their intent to demean the revered idea and reality of marriage, the petitioners' claims would be of a different order. But that is neither their purpose nor their submission.

(7) It would misunderstand these men and women to say they disrespect the idea of marriage. Their plea is that they do respect it, respect it so deeply that they seek to find its fulfillment for themselves.

These examples reflect the argument in which the majority insists on the right to personal choice regarding marriage, which stems from the concept of individual autonomy.

We now turn to examine the role and use of DISRESPECT and its related lexis in dissenting opinions. It is striking to see the extent to which these negatively-loaded words are used in direct citations from majority opinions. In Example 8, the majority's argument is encapsulated and its voice echoed. The rhetorical effect of creating the string of quasi-synonymous verbs is to exaggerate and refute the point made by the majority. The evaluation of same-sex couples' action is attributed to the majority. This is followed by the terse rebuttal which makes the majority opinion sound misguided and irrelevant:

(8) The majority's driving themes are that marriage is desirable and petitioners desire it. The opinion describes the "transcendent importance" of marriage and repeatedly insists that petitioners do not seek to "'demean', 'devalue', 'denigrade', or 'disrespect' the institution". Nobody disputes those points.

(9) But the majority says that the supporters of this Act acted with malice with the purpose to disparage and to injure same-sex couples. It says that the motivation for DOMA was to demean, to impose inequality, to impose. ... a stigma, ante, at 21 ; to deny people equal dignity, to brand gay people as unworthy, and to humiliate their children, (ibid). I am sure these accusations are quite untrue. 
Example 9 uses a similar tactic. It attempts to show that the majority in its negative evaluation of the DOMA, effectively targets supporters of the federal law, and in more general terms, those who defend traditional marriage (see also Example 10). As can be seen in Examples 1-5, the majority opinion targets DOMA, which means that the federal law is placed against a clearly defined class of citizens (referred to as 'gays and lesbians' and 'same-sex couples'). In their rebuttal, the dissent implies that there is a shift from the negative evaluation of the federal statute to a negative evaluation of another group of citizens, i.e. those who support traditional marriage. This is a far-reaching and important argument as it underscores the social conflict by positing two groups of citizens against each other.

Example 10 shows how the dissenting opinion turns the majority's argument on its head by retaining the characteristic string of quasi-synonymous verbs in order to provide a positive evaluation of the traditional stance on marriage. This is accomplished by resorting to an argument from analogy: defending traditional marriage can be compared to defending the Constitution, with the Constitution held in indisputable value, cherished by American people irrespective of their political views.

(10) "But to defend traditional marriage is not to condemn, demean, or humiliate those who would prefer other arrangements, any more than to defend the Constitution of the United States is to condemn, demean, or humiliate other constitutions. To hurl such accusations so casually demeans this institution".

Just as in Example (9), this excerpt also ends with a succinct line containing an explicit evaluation of the majority's proposition. The evaluation is manifested not only by means of the repeated use of demean but the majority's proposition is labelled as 'accusation'. Examples 8-10 illustrate the extent to which intertextuality plays a central role in the dissenting opinion.

\section{The category of RESPECTED in majority and dissenting opinions}

The category of RESPECTED is illustrated by focusing on how the word 'dignity' tends to be used in the judicial opinions. Dignity is a legitimate and socially recognized value. As Fairclough and Fairclough (2012: 24) suggest moral values can appear in arguments "as (social, institutional) facts in factual premises, and as actual concerns in motivational premises". 
In other words, they can enter arguments as premises. This is illustrated in Example 11.

(11) There is dignity in the bond between two men or two women who seek to marry and in their autonomy to make such profound choices.

Examples 12-14 illustrate how the majority opinions view dignity in terms of its deficit, as something lacking and highly desirable for same-sex couples. They stress that dignity is an individual's right, and the role of law and the state is to ensure dignity for all its citizens (emphasis added):

(12) They ask for equal dignity in the eyes of the law.

(13) When the State used its historic and essential authority to define the marital relation in this way, its role and its power in making the decision enhanced the recognition, dignity, and protection of the class in their own community.

(14) Until recent years, many citizens had not even considered the possibility that two persons of the same sex might aspire to occupy the same status and dignity as that of a man and woman in lawful marriage.

This reference to dignity suggests that dignity is a value which functions as a premise in a practical argument (Fairclough \& Fairclough 2012). It can be a reason for action because it underlies a commonly recognized goal of ensuring equal treatment and dignity to all citizens residing lawfully in a state.

If we move on to consider how dignity is used in dissenting opinions, we notice that it serves to signal another site of contention. The excerpt in Example 15 is yet another example of a dialogic relation between the majority and dissenting opinions. In its opinion, the dissent provides a direct citation from the majority opinion which constitues a positive evaluation of a relationship between two people of the same sex and their endeavours to acquire the right to marry. This attributed evaluation is used in an argument to absurdity (argumentum ad absurdum) when the question is posed about dignity in a polyamorous relationship. In other words, the dissent enters into a dialogue with the majority's opinion by responding and undermining its validity.

(15) "If "there is dignity in the bond between two men or two women who seek to marry and in their autonomy to make such profound choices,' ante, at 13, why would there be any less dignity in the bond between three people who, in exercising their autonomy, seek to make the profound choice to marry? 
Example 16 illustrates how evaluation works at different levels. The first sentence assigns an epistemic status to the majority's proposition. ${ }^{7}$ The proposition is assessed as musings which in legal discourse is open to unfavourable interpretation because it cannot be verified objectively. The unfavourable evaluation is reinforced through the use of the explicitly negative phrase deeply misguided.

(16) The majority 's musings are thus deeply misguided, but at least those musings can have no effect on the dignity of the persons the majority demeans.

We can recall that the majority opinions unequivocally pointed towards the federal or state legislation as demeaning to same-sex couples. The dissenting opinion shifts the focus of attention from same-sex couples to people embracing traditional marriage. They are placed as potential victims whose dignity is in jeopardy. The choice of words which carry the negative evaluation of the majority's stance is far from accidental. The dissent uses the lexeme demean to stress that majority does exactly what it accuses others of doing. Put differently, it implies that the majority's opinion is hypocritical.

(17) Along the way, it [The Court 's decision] rejects the idea - captured in our Declaration of Independence - that human dignity is innate and suggests instead that it comes from the Government.

The final example shows that the judges are divided over how dignity should be conceived and the role of the court. The dissent's argument is that the Supreme Court is engaged in judicial activism which involves acting in contravention of the people's will entrenched in the American Constitution. The limited space for this paper precludes a more extensive discussion on how the Constitution is relied upon in the two types of opinion.

\section{Conclusion}

In this paper, I have attempted to demonstrate the role of selected value-laden words and the co-occurring evaluative language in judicial argumentation. The Court, writing the majority opinions framed the question as one of basic fairness and human dignity. The keyword analysis has been demonstrated to be an effective tool to identify prevalent topics, the "aboutness" of texts, which provides a list of candidate terms for potential values relied upon by judges justfying their decisions. Terms such as dignity, freedom, liberty, tradition, etc. can be treated as a useful starting point for analyzing the axiomatic aspects of judicial opinions. The keyword 
analysis combined with the analysis of key semantic domains has identified (DIS)RESPECT as a statistically salient lexical domain marked by a strong evaluative polarity in both types of judicial opinion.

The scrutiny of selected lexical items belonging to the domain, such as demean and dignity has revealed how evaluative language is integrated into much of the argumentation contained in both the majority and dissenting opinions. It appears that (DIS)RESPECT used in reference to the litigants serve as foundation for much of the argumentation found in the majority opinions in the two cases. In the majority argument same-sex marriage constitutes one of the fundamental rights and liberties, which is breached by either federal or state legislation. One of the major claims is that prohibiting same-sex marriage is not only unconstitutional but it deprives same-sex couples of their dignity because they are denied the right to intimate association, protection for their children and families and a host of financial benefits. The dissenting opinions are characterised by extensive intertextuality and dialogical patterns maintained through direct citations of the majority opinions. The theme of (dis)repect tends to be echoed in dissenting opinions in subsequent underminers and rebuttals. While the debate to a large extent centres upon the definitions of marriage and liberty (Macagno 2016), it is surprising to see how much the notion of respect has been integrated into the judicial argumentation. Further research should focus on other classes of keywords and key semantic domains with a view to building a more complete axiomatic picture of these landmark civil rights cases.

\section{N O T E S}

1 The book was accessed via Google Books and no page numbers are available.

2 The information about the legal background to this case was adapted from the Oyez (a free law project from Cornell's Legal Information Institute) website available at https://www.oyez.org/cases/2012/12-307

3 See Goźdź-Roszkowski 2017 for an up-to-date overview of linguistically-oriented studies of evaluation in judicial discourse.

4 http://ucrel.lancs.ac.uk/wmatrix/

5 A preliminary and exploratory analysis of keywords generated through reference to the BNC sample of written English was carried out using the Wmatrix 3. See also GoźdźRoszkowski 2011: 35-38 for a more detailed discussion of the Keyword Analysis applied to the study of legal texts.

${ }^{6}$ See the discussion in Macagno 2016 on issues related to defining the concepts of marriage and liberty.

7 See Goźdź-Roszkowski 2018 for a discussion of how epistemic status can be evaluated in judicial discourse. 
Breeze, R. 2011. 'Disciplinary values in legal discourse: a corpus study.' Iberica 21, 93-116.

Brostoff, T. \& Sinsheimer, A. 2003. Legal English. An Introduction to the Legal Language and Culture of the United States. New York: Oceana Publications, Inc.

Fairclough, I. and Fairclough, N. 2012. 'Values as premises in practical arguments: Conceptions of justice in the public debate over bankers' bonuses' in: van Emerson, F. and Garssen, B. (eds.) Exploring Argumentative Contexts, pp. 23-41. Amterdam: Benjamins.

Goźdź-Roszkowski, S. 2018. 'Facts in Law: a comparative study of fact that and its phraseologies in American and Polish judicial discourse' in GoźdźRoszkowski, S. and Pontrandolfo, G. (eds.). Phraseology in Legal and Institutional Settings. A Corpus-based Interdisciplinary Perspective, pp. 143-159. London: Routledge.

Goźdź-Roszkowski, S. 2017. "Justice with an attitude?" - towards a corpus-based description of evaluative phraseology in judicial discourse' in Pęzik, P. and Waliński, J. (eds.) Language, Corpora and Cognition, pp. 107-127. Frankfurt am Main. Peter Lang.

Goźdź-Roszkowski, S. 2011. Patterns of Linguistic Variation in American Legal English. A Corpus-based Study. Frankfurt am Main. Peter Lang.

Goźdź-Roszkowski, S. and Pontrandolfo, S. 2013. 'Evaluative patterns in judicial discourse: a corpus-based phraseological perspective on American and Italian criminal judgments.' International Journal of Law, Language and Discourse, vol 13, Issue 2, pp. 9-69.

Macagno, F. 2016. Defining Marriage: Classification, Interpretation, and Definitional Disputes. Informal Logic, 36.3, pp. 309-332.

Mazzi, D. 2010. 'This Argument Fails for Two Reasons... A Linguistic Analysis of Judicial Evaluation Strategies in US Supreme Court Judgements.' International Journal for the Semiotics of Law 23 No. 4: 373-385.

Partington, A., Duguid, A. and Taylor, C. (eds.). 2013. Patterns and Meanings in Discourse. Theory and practice in corpus-assisted discourse studies $(C A D S)$. Amsterdam: John Benajmins.

Partington, A. 2004. 'Corpora and Discourse: A most congruous beast' in A. Partington, J. Morley \& L. Haarman (eds.) Corpora and Discourse., 11-20. Bern: Peter Lang.

Perelman, Ch. and Olbrechts-Tyteca, L. 1969. The New Rhetoric. A Treatise on Argumentation. Notre Dame: University of Notre Dame.

Rayson, Paul. 2008. 'From key words to key semantic domains.' International Journal of Corpus Linguistics. 13:(4): 519-549.

Scott, M. 2008. WordSmith Tools Help Manual. Version 5.0. Liverpool. Lexical Analysis Software. 
Values and Valuations in Judicial Discourse...

Thompson, G. \& Alba Juez L. 2014. Evaluation in Context. Amsterdam: John Benajmins.

Thompson, G. and Hunston, S. 2000. Evaluation. An Introduction. In: Hunston, S. and Thompson, G. (eds.) Evaluation in Text. Authorial Stance and the Construction of Discourse. pp. 1-27. Oxford: OUP.

Williams, R. 1995. Keywords: A Vocabulary of Culture and Society. Oxford: Oxford University Press.

Zimmerman, J. 2015. Wartości w prawie administracyjnym. [Values in Administrative Law) Warszawa: LEX. Wolters Kluwer. 